\title{
PERBANDINGAN KELIMPAHAN MAKROZOOBENTOS DI EKOSISTEM LAMUN PADA SAAT BULAN PURNAMA DAN PERBANI DI PULAU PANGGANG KEPULAUAN SERIBU JAKARTA
}

\section{COMPARISON OF MACROZOOBENTHIC ABUNDANCE IN SEAGRASS ECOSYSTEM DURING FULL AND NEAP MOON AT PANGGANG ISLAND SERIBU ISLANDS}

\author{
Iswandi Wahab*, Mujizat Kawaroe, dan Hawis Madduppa \\ Departemen Ilmu dan Teknologi Kelautan, FPIK-IPB, Bogor \\ *E-mail: hawis@apps.ipb.ac.id
}

\begin{abstract}
Macrozoobenthic is one of the organisms whose existence is widely present in the seagrass ecosystem. This study aimed to analyze the differences in individual abundance and macrozoobenthic species in full-moons and neap, to see the correlation of macrozoobenthic abundance with seagrass closure, and to know the contribution of macrozoobenthic species to seagrass habitat. The study was conducted in Panggang Island with 3 makrozoobenthic observation stations in the seagrass ecosystem at March and April 2016. Makrozoobenthic data collection in seagrass systematically using $1 \times 1 \mathrm{~m}$ quadrant transect method and $10 \mathrm{~cm}$ diameter corer for infauna. Analyzing the density, seagrass cover and macrozoobenthic abundance. Analysis statistics of macrozoobenthic abundance data using ANOVA test, macrozoobenthic density correlation with seagrass cover using simple linear regression and contribution of species on full moon and neap using SIMPER analysis. The result of this research shows that there is no real difference of macrozoobenthic individual abundance in full moon and neap. While the species obtained significant significant differences. The SIMPER analysis shows the highest contribution of macrozoobenthic species in each station on the full moon and the neap is the species of Cerithium salebrosum. Conclusions The density of macrozoobenthic species shows a marked difference in the full moon and the neap, but not the individual abundance.
\end{abstract}

Keywords: abundance, macrozoobenthic, Panggang islands

\begin{abstract}
ABSTRAK
Makrozoobentos merupakan salah satu organisme yang keberadaannya banyak terdapat di ekosistem lamun. Tujuan penelitian untuk menganalisis perbedaan kelimpahan individu dan spesies makrozoobentos di bulan purnama dan perbani, melihat korelasi kepadatan makrozoobentos dengan penutupan lamun, dan mengetahui kontribusi spesies makrozoobentos pada habitat lamun. Penelitian ini dilakukan di pulau panggang dengan 3 stasiun pengamatan makrozoobentos di ekosistem lamun pada bulan Maret dan April 2016. Pengambilan data makrozoobentos di lamun secara sistematis menggunakan metode transek kuadran $1 \mathrm{x} 1 \mathrm{~m}$ dan corer berdiameter $10 \mathrm{~cm}$ untuk infauna. Menganalisis nilai kerapatan, tutupan lamun dan kelimpahan makrozoobentos. Analisis data statistik kelimpahan makrozoobentos menggunakan uji ANOVA, korelasi kepadatan makrozoobentos dengan tutupan lamun menggunakan regresi linear sederhana dan kontribusi spesies pada bulan purnama dan perbani menggunakan analisis SIMPER. Hasil penelitian didapatkan tidak adanya perbedaan nyata kelimpahan individu makrozoobentos di bulan purnama dan perbani. Sedangkan spesies didapatkan perbedaan nyata yang signifikan. Korelasi positif antara kepadatan makrozoobentos dengan tutupan lamun dibulan purnama, sedangkan pada bulan perbani berkorelasi negative. Analisis SIMPER menunjukan kontribusi spesies makrozoobentos tertinggi di tiap-tiap stasiun di bulan purnama dan perbani adalah spesies Cerithium salebrosum. Kesimpulan kepadatan spesies makrozoobentos menunjukkan perbedaan nyata di bulan purnama dan perbani, namun tidak pada kelimpahan individu.
\end{abstract}

Kata kunci: kelimpahan, makrozoobentos, pulau Panggang 


\section{PENDAHULUAN}

Produktifitas lamun yang tinggi di suatu perairan berkaitan erat dengan laju produktifitas organisme yang berasosiasi di dalamnya dan menjadi sumber penghidupan. Makrozoobentos merupakan salah satu organisme yang keberadaannya cukup banyak terdapat di ekosistem lamun dan memanfaatkan lamun sebagai habitat dalam siklus hidupnya. Adanya asosiasi biota ini menyebabkan terjadi suatu interaksi yang kompleks dengan ekosistem lamun. Kelompok fauna yang berada pada lamun umumnya didominasi oleh hewan makrozoobentos seperti teripang, kepiting (Arthopoda), bulu babi, bintang laut, kerang, bintang mengular (Echinodermata), keong (Moluska), sponge (Porifera), dan udang (de Wilde, 1989). Distribusi organisme makrozoobentos biasanya mengikuti pola arus pasang dan surut air laut dan tidak homogen dalam menempati lingkungan perairan.

Proses pasang surut yang terjadi pada suatu perairan sangat berpengaruh terhadap distribusi dan kelimpahan biota-biota laut termaksud makrozoobentos. Hal ini dikarenakan pola pasang surut berhubungan dengan fase bulan. Pola pasang purnama (full moon) terjadi pada fase bulan baru dan purnama sedangkan pola pasang perbani terjadi pada bulan seperempat dan tiga perempat, dimana kekuatan pasang yang terjadi pada bulan purnama lebih besar dari pada kekuatan pasang bulan perbani. Perbedaan kekuatan pasang ini secara teoritis dapat diketahui mempengaruhi kelimpahan spesies makrozoobentos antara periode waktu purnama dan perbani disebabkan sirkulasi masa air antara kedua periode bulan berbeda. Hal ini juga tidak terlepas dari besarnya pengaruh dinamika parameter lingkungan di bulan purnama dan perbani dimana kondisi besarmya ruang pergerakan dan pendistribusian sumber makanan serta parameter fisika-kimia. Menurut hasil penelitian Romimoharto dan Juana (2004), pengaruh periode bulan pada mintakat pasang surut sangat terkait dengan gejala pasang surut dan pencahayaan bulan sehingga secara bilogis mengstimulasi biota laut dalam hal penyebaran, pemangsaan dan pemijahan.

Sebuah perbedaan besar dalam sirkulasi masa air antara periode bulan perbani dan purnama menggambarkan kapasitas masa air berupa arus pasang surut untuk mendistribusikan sedimen, makanan dan organik lainya. Sifat fisika-kimia sedimen, seperti kondisi suhu, salinitas dan oksigen, juga dipengaruhi oleh arus pasang surut (Day et al., 1989). Bahwa pasang surut di saat fase bulan baru baik purnama dan perbani dan puncak bulan baru baik purnama dan perbani berdampak pada struktur ekosistem intertidal. Pendekatan pengamatan berdasarkan perbedaan bulan purnama (full moon) dan bulan perbani (neap moon) ini belum banyak dilakukan terutama di Indonesia. Namun banyak proses yang berbeda serta karakteristik fisiografi dan substrat yang mempengaruhi pola temporal dan spasial baik kepadatan dan kelimpahan spesies makrozoobentos (Legendre et al.,1997).

Banyak penelitian makrozoobentos pada komunitas padang lamun hanya fokus pada perbandingan kepadatan makrozoobentos di ekosistem lamun secara umum. Penelitian tentang struktur komunitas lamun beserta biota laut yang berasosiasi telah banyak dilakukan di Indonesia terus menunjukkan peningkatan dalam dua dekade terakhir ini (Tomascik et al., 1997). Namun penelitian biota asosiasi yang dilakukan di daerah lamun ini, umumnya hanya mencakup spesies-spesies yang hidup di atas permukaan substrat saja (epifauna) sedangkan infauna masih sangat sedikit dilakukan.

Mengacu pada konsep diatas, maka sebuah pengetahuan dasar dalam memahami biota asosiasi dengan ekosistem di daerah intertidal dan khususnya organisme makrozoobentos. Pendekatan pengamatan berdasarkan perbedaan bulan purnama dan bulan perbani ini belum banyak dilakukan terutama di Indonesia. Adanya suatu pengembangan metode dalam melihat kelimpahan makro- 
zoobentos pada suatu perairan berdasarkan habitat dan periode waktu bulanpurnama dan perbani menjadi alternative sampling yang lebih mudah dan efektif untuk mengetahui kelimpahan makrozoobentos yang ada di suatu perairan.

Metode pengamatan organisme berdasarkan periode waktu bulan purnama dan perbani merupakan suatu studi kajian yang masih baru, karena metode ini pernah diterapkan di Indonesia untuk melihat kelimpahan ikan gobidae dan siganus di daerah intertidal Teluk Ambon (Latuconsina, 2012). Pendekatan pengamatan dengan metode ini belum dilakukan pada organisme makrozoobentos di padang lamun, sehingga pada penelitian ini mencoba untuk menerapkan metode pengamatan berdasarkan periode bulan purnama dan perbani terhadap organisme makrozoobentos di habitat ekosistem lamun di Pulau Panggang Kepulauan Seribu Jakarta.

Pengamatan pada periode bulan purnama dan perbani dilakukan dengan tujuan untuk mengetahui kontribusi spesies makrozoobentos tertentu pada bulan purnama dan perbani di habitat lamun, dan apakah terdapat perbedaan kelimpahan individu dan spesies makrozoobentos pada bulan purnama dan perbani, serta adanya korelasi kepadatan spesies makrozoobentos dengan penutupan lamun. Berdasarkan uraian diatas, maka dilakukan penelitian tentang "Perbandingan Kelimpahan Makrozoobentos di Ekosistem Lamun pada saat Bulan Purnama dan Perbani di Pulau Panggang Kepulauan Seribu Jakarta”.

\section{METODE PENELITIAN}

\subsection{Lokasi Penelitian}

Penelitian ini dilaksanakan pada bulan Maret sampai April 2016 di Ekosistem Lamun di Perairan Pulau Pangang, Kepulauan Seribu, Jakarta. Sampling saat fase purnama dilakukan pada bulan Maret dan April tanggal 14-15 dan 2-3 berdasarkan kalender hijriyah, sedangkan perbani tanggal 6-7 dan 26-27 hijriyah. Terdapat 3 stasiun pengamatan yang ditetapkan berdasarkan tingkat kompleksitas dan vegetasi yang berbeda dengan melihat kerapatan dan penutupan jenis lamun serta kelimpahan makrozoobentos.

\subsection{Prosedur Pengambilan Data}

Pengambilan data makrozoobentos di vegetasi lamun dilakukan secara sistematis, menggunakan metode line transek kuadran berukuran 1 x $1 \mathrm{~m}$ mengacu (English et al., 1997). Sebelum dilakukan pengambilan data, terlebih dahulu untuk penarikan garis transek kuadran 100 meter ke arah laut di mulai dari awal terdapat lamun hingga ujung batas keberadaan lamun. Penentuan dan penempatan plot pengambilan sampel baik lamun dan makrozoobentos di tiap stasiun pada garis transek kuadran yang sama (permanen). Pengambilan sampel dilakukan pada titik yang sama di masing-masing kuadran dengan tiga kali pengulangan tiap stasiun pada kedua bulan.

Tahapan dalam pengambilan data melalui identifikasi jenis, menghitung kelimpahan makrozoobentos, dan tutupan jenis untuk lamun. Identifikasi jenis lamun mengacu pada (Waycott et al., 2004) dan makrozoobentos Dharma (1992 dan 2005). Pengambilan data makrozoobentos di vegetasi lamun dengan menggunakan corer diameter $10 \mathrm{~cm}$ (Cochran, 1977) di tancapkan pada sedimen hingga kedalaman $\pm 20 \mathrm{~cm}$ (untuk infauna). Sampel yang telah diambil lewat corer segera disaring dan dipisahkan antara serasah kasar dan lumpur menggunakan saringan halus (mesh size 0,5 mm). Penanganan sampel corer selanjutnya dilakukan dengan beberapa tahap yaitu tahap penyaringan, penyortiran, pengawetan dan identifikasi dengan menggunakan mikroskop binokuler. Sedangkan spesies permukaan substrat dihitung jumlah individu spesies pada kuadran saat fase bulan Purnama dan Perbani. 


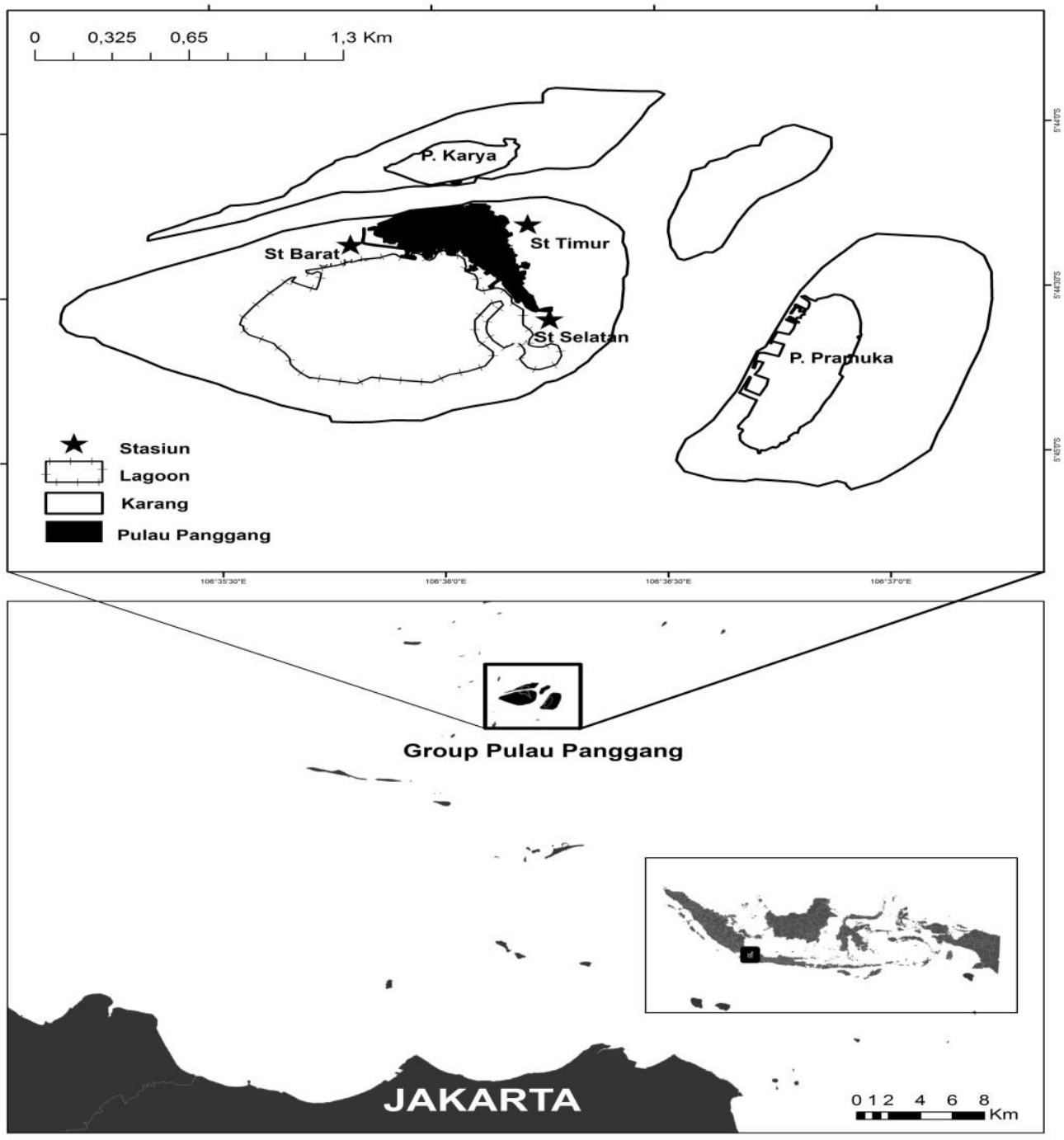

Gambar 1. Lokasi dan stasiun penelitian di perairan Pulau Panggang.

Data karakteristik lingkungan perairan diperoleh melalui pengukuran parameter suhu air, arus, salinitas, $\mathrm{pH}$ dan oksigen terlarut (Dissolved Oxygen/DO) yang dilakukan secara in-situ di lapangan. Sedangkan data substrat perairan dilakukan analisis Laboratorium Lingkungan Budi Daya Perairan Fakultas Perikanan dan Ilmu Kelautan Institut Pertanian Bogor. Analisis hasil substrat dimasukan ke dalam program segitiga miller untuk mengetahui komposisi butiran substrat (USDA, 2012).

Hasil analisis uji korelasi parameter lingkungan perairan didapatkan nilai yang berkorelasi dengan makrozoobentos pada bulan purnama adalah salinitas 31,23 ppt, pasir kasar $24,73 \%$, pasir sangat halus $12,13 \%$ di stasiun barat. Stasiun timur adalah suhu $31,63^{\circ} \mathrm{C}$, arus $0,47 \mathrm{~m} /$ det. Sedangkan stasiun selatan adalah pasang surut $52 \mathrm{~cm}$, pasir kasar $24,06 \%$ dan pasir halus $4,58 \%$. Sedangkan parameter lingkungan perairan yang berkorelasi dengan makrozoobentos pada bulan perbani adalah salinitas $31,17 \mathrm{ppt}$, pasang surut 29,67 cm, pasir halus 5,43\% distasiun barat. Stasiun timur, oksigen terlarut (DO) 8,23 mg/l, pasir kasar 24,53\%, pasir halus $3,96 \%$. dan stasiun selatan, pasir halus 4,58\%, dan salinitas 31,43 ppt. 


\subsection{Analisis Data}

\subsubsection{Kelimpahan Individu Spesies Makrozoobentos}

Kelimpahan individu dan spesies makrozoobentos di bulan purnama dan perbani dianalisis menggunakan uji One-way (ANOVA) dengan bantuan Program software Excelstat-Pro 7.5.2, Pearson Prentice Hall (2007). Sedangkan analisis kesamaan jenis dan kontribusi spesies makrozoobentos menggunakan Nonmetrik Multidimensional Scaling (nMDS) dan SIMPER dengan perangkat lunak PRIMER v7 (Clarke, 1993).

\subsubsection{Korelasi Makrozoobentos dengan Penutupan Lamun}

Korelasi kepadatan makrozoobentos dan penutupan lamun dianalisis dengan menggunakan analisis regresi linier sederhana dengan menggunakan software Excelstat-Pro 7.5.2 Pearson Prentice Hall (2007) dan menghitung keberadaan populasi makrozoobentos di pulau Panggang.

\section{HASIL DAN PEMBAHASAN}

\subsection{Kelimpahan Individu Spesies Makrozoobentos}

Hasil analisis ragam menggunakan One-way (ANOVA), untuk mengetahui tingkat perbedaan kelimpahan baik individu dan spesies antar priode waktu bulan purnama dan bulan perbani di perairan Pulau Panggang Kepulauan Seribu Jakarta.

Tabel 1. Hasil ANOVA untuk kelimpahan individu dan spesies makrozoobentos di bulan purnama dan perbani $(* \mathrm{p}<0,05$, ns tidak signifikan).

\begin{tabular}{lccc}
\hline \multicolumn{1}{c}{ Uji One-way } & F & $\begin{array}{c}\text { P. } \\
\text { ANOVA }\end{array}$ & V $(\rho)$ \\
\hline $\begin{array}{l}\text { Kelimpahan } \\
\text { Individu }\end{array}$ & 1,45 & 0,35 & ns \\
$\begin{array}{l}\text { Kelimpahan } \\
\text { Spesies }\end{array}$ & 72 & 0,13 & $*$ \\
\hline
\end{tabular}

Hasil uji analisis menggunakan OneWay Anova didapatkan bahwa nilai korelasi individu di bulan purnama dan perbani yaitu (p.value 0.35), sedangkan pada spesies yaitu (p.value 0.13). Berdasarkan analisis Anova menunjukkan tidak adanya perbedaan signifikan rata-rata kelimpahan individu makrozoobentos antara bulan purnama dan perbani pada semua stasiun pengamatan $\left({ }^{n s} \mathrm{p}\right.$ $>$ 0,05). Nilai perbedaan kelimpahan makrozoobentos pada kedua periode bulan yang tidak berbeda diduga terkait bentuk kanopi, kerapatan vegetasi lamun, struktur fisik substrat dan fase bulan saat sampling data. Nilai kelimpahan individu antara kedua fase bulan secara kuantitatif berbeda yaitu bulan purnama 613 (Ind) dan perbani 761 (Ind). Namun hasil analisis secara statistik tidak adanya perbedaan signifikan. Hal ini diduga karena vegetasi lamun dan substrat yang ada pada semua stasiun memiliki jenis dan struktur yang sama, namun kondisi parameter lingkungan dan fase bulan sampling data berbeda. Komposisi lamun yang didominasi oleh Cymodocea rotundata, Thalassia hempricii, dan Enhalus acoroides serta substrat berpasir yang dominan mengindikasikan bahwa individu makrozoobentos yang terdapat pada habitat lamun tetap sama. Menurut Apha (1992), dalam lingkungan yang relative stabil, komposisi dan kelimpahan makrozoobentos relative tetap. Setiap komunitas memberikan respon terhadap perubahan kualitas perairan dan habitat dengan cara penyesuaian diri pada struktur komunitas yang ada. Sedangkan kategori kelimpahan spesies disaat bulan purnama dan perbani didapatkan perbedaan nyata yang sangat signifikan $(* p<0,05)$. Sehingga diketahui bahwa terdapat perbedaan kelimpahan spesies makrozoobentos diantara kedua periode waktu tersebut. Perbedaan kelimpahan spesies makrozoobentos antara periode bulan purnama dan bulan perbani diduga kuat terkait karakteristik kemunculan spesies yang lebih banyak disaat bulan purnama sebesar 194 spesies. Hal ini terkait dengan besarnya 
pengaruh parameter lingkungan di bulan purnama, dimana kondisi besarnya ruang pergerakan dan pendistribusian sumber makanan serta parameter fisika-kimia. Menurut Romimohtarto dan Juana (2004), pengaruh periode bulan pada mintakat pasang surut sangat terkait dengan gejala pasang surut dan pencahayaan bulan sehingga secara biologis mengstimulasi biota laut dalam hal penyebaran, pemangsaan dan pemijahan.

Secara umum kelimpahan makrozoobentos dipengaruhi oleh banyak faktor diantaranya jenis substrat, habitat tempat hidup, stabilitas lingkungan, produktifitas, kompetisi dan sumber makanan. Menurut Mc Lusky (1989), keberadaan organisme makrozoobentos bervariasi sesuai dengan perubahan kondisi lingkungan.

Hasil analisis kesamaan jenis makrozoobentos di masing-masing stasiun menggunakan Non-metric Multidimensional Scaling (nMDS).
Berdasarkan nilai indeks kesamaan Bray-curtis menunjukkan, dari keseluruhan stasiun memiliki indeks kesamaan jenis makrozoobentos lebih dari $75 \%$, dengan pola sebaran acak pada masing-masing lokasi dan membentuk sudut terpisah antara bulan purnama dan perbani. Nilai indeks kesamaan makrozoobentos yang lebih rendah (40\%), ditemukan di stasiun barat (B3) saat bulan perbani.

Perbedaan yang signifikan dalam komunitas makrozoobentos di antara lokasi pengamatan terkait kelimpahan spesies di bulan purnama dan perbani dapat dilihat di ANOSIM (Tabel 2) dan plot nMDS (Gambar 2). Berdasarkan nMDS diatas dapat dilihat spesies makrozoobentos di pulau Panggang kepulauan seribu terbagi menjadi 3 kelompok dengan pola sebaran acak, namun berada pada sudut berbeda antara bulan purnama dan perbani. Pola kelompok (Grup) yang terbentuk terlihat adanya kecendrungan pengelompokan spesies makrozoobentos berdasarkan lokasi dan periode (Fase) bulan.

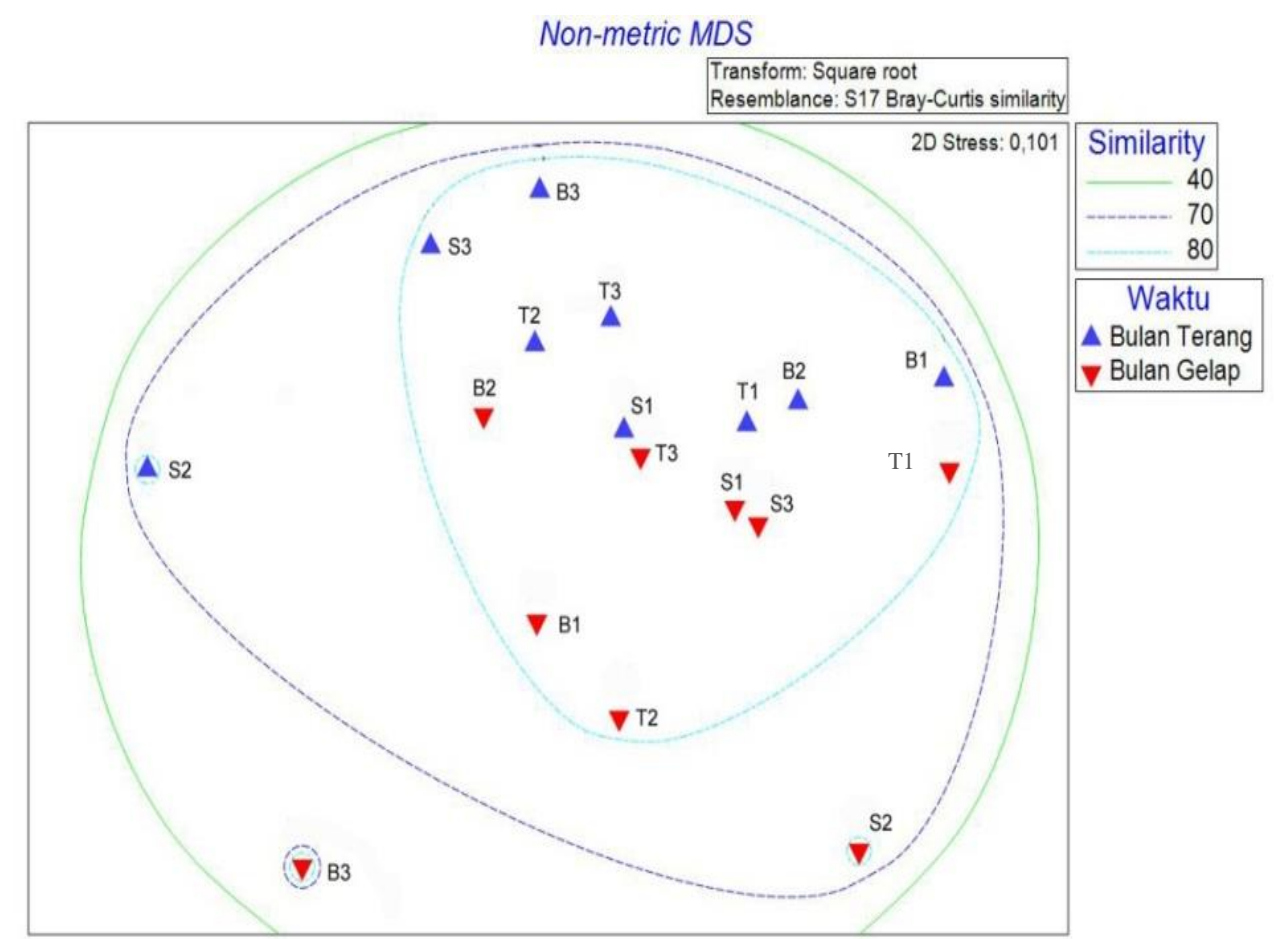

Gambar 2. Kesamaan jenis makrozoobentos pada masing-masing stasiun di Pulau Panggang, berdasarkan analisis Non-metric Multidimensional Scaling (nMDS) menurut nilai rata-rata kelompok. 
Tabel 2. Hasil uji ANOSIM two-way, berdasarkan kelimpahan semua spesies di masingmasing lokasi pada bulan purnama dan perbani.

\begin{tabular}{llrrc}
\hline \multicolumn{5}{c}{ Kelimpahan Makrozoobentos } \\
\hline Uji & Faktor & Pasangan Uji & $\rho$ & $p(\rho)$ \\
\hline Persilangan & Bulan & & 0,078 & $*$ \\
& & Barat - Timur & 0,093 & $*$ \\
& & Barat - Selatan & 0,315 & $* *$ \\
& & Timur - Selatan & $-0,093$ & n.s. \\
\hline
\end{tabular}

Keterangan: $\left(* \rho<0,05,{ }^{* *} \rho<0,01\right.$, n.s. tidak signifikan)

Hal yang menarik dari grafik nMDS adalah pada kelompok dengan indeks kesamaan jenis $40 \%$. Dimana pada lokasi barat perbani membentuk kelompok yang jauh dari kelompok lainya. Namun perlu diketahui bahwa, pembentukan kelompok yang jauh pada lokasi ini tidak hanya berkorelasi pada posisi tempat saja. Faktor periode/fase bulan yang sangat berpengaruh pada kelompok B3 ini. Hal ini dikarenakan letak lokasi barat berhadapan langsung dengan laut lepas, sehingga pengaruh gelombang yang masuk cukup besar. Selain itu, tingginya surut permukaan air di lokasi barat tidak terlalu rendah saat bulan perbani. Hasil analisis menggunakan uji SIMPER, didapatkan spesies makrozoobentos yang berkontribusi paling tinggi di bulan purnama (tabel 3 (a), terdiri dari 8 spesies yaitu Cerithium salebrosum 26,57\%, Troncus sp $24,77 \%$, Cerithium punctatum $16,44 \%$, Rhinoclavis vertagus $3,05 \%$, Euthria sp 3,01\%, Strombus urceus 2,88\%, Cerithium litteratum 2,68\%, Cerithium balteatum $1,58 \%$, dengan nilai kontribusi paling tinggi adalah spesies Cerithium salebrsosum 26,57\%. Sedangkan pada bulan perbani (tabel 3 (b), didapatkan 4 spesies

Tabel 3. Komposisi spesies makrozoobentos yang paling tinggi berkontribusi di bulan purnama (a) dan bulan perbani (b), pada keseluruhan stasiun menggunakan SIMPER (persentase kemiripan-kontribusi spesies).

\begin{tabular}{|c|c|c|c|c|}
\hline Jenis Makrozoobentos & $\begin{array}{c}\text { Av. } \\
\text { Abundance }\end{array}$ & $\begin{array}{c}\text { Av. } \\
\text { Similarity }\end{array}$ & $\begin{array}{c}\text { Contribution } \\
\% \\
\end{array}$ & Cumulative \% \\
\hline Cerithium salebrosum & 1,77 & 9,24 & 26,57 & 26,57 \\
\hline Troncus sp & 1,69 & 8,62 & 24,77 & 51,34 \\
\hline Cerithium punctatum & 1,33 & 5,62 & 16,14 & 67,48 \\
\hline Rhinoclavis vertagus & 0,66 & 1,06 & 3,05 & 70,53 \\
\hline Euthria sp & 0,69 & 1,05 & 3,01 & 73,54 \\
\hline Strombus urceus & 0,59 & 1,00 & 2,88 & 76,42 \\
\hline Cerithium litteratum & 0,56 & 0,93 & 2,68 & 79,10 \\
\hline Cerithium balteatum & 0,47 & 0,55 & 1,58 & 80,68 \\
\hline \multicolumn{5}{|c|}{ b. Bulan Perbani (Average similarity 47,06 ) } \\
\hline Jenis Makrozoobentos & $\begin{array}{c}\text { Av. } \\
\text { Abundance }\end{array}$ & $\begin{array}{c}\text { Av. } \\
\text { Similarity }\end{array}$ & $\begin{array}{c}\text { Contribution } \\
\%\end{array}$ & Cumulative \% \\
\hline Cerithium salebrosum & 2,07 & 13,42 & 28,51 & 28,51 \\
\hline Cerithium punctatum & 1,67 & 9,16 & 19,47 & 47,98 \\
\hline Rissiona multicostata & 1,68 & 8,60 & 18,27 & 66,25 \\
\hline Euthria sp & 1,32 & 7,19 & 15,27 & 81,52 \\
\hline
\end{tabular}


makrozoobentos yang berkontribusi yaitu Cerithium salebrosum 28,51\%, Cerithium punctatum 19,47\%, Rissiona multicostata 18,27\% dan Euthria sp 15,27\% dengan nilai kontibusi spesies paling tinggi adalah Cerithium salebrsosum $28,51 \%$.

Spesies Cerithium salebrosum merupakan yang paling tinggi kontribusi di bulan purnama. Tingginya nilai kepadatan dari spesies Cerithium salebrosum pada masing-masing stasiun di bulan purnama menyebabkan kontribusi dari spesies ini sangat tinggi. Keberadaan 8 spesies makrozoobentos di bulan purnama ini merupakan kategori dari kelas gastropoda, dan memiliki nilai kepadatan yang tinggi pada masing-masing stasiun, sehingga tergolong spesies yang lebih berkontribusi di bulan purnama dari total 46 spesies yang ada. Sementara di bulan perbani 4 spesies makrozoobentos dari kelas gastropoda lebih berkontribusi dari total 39 spesies. Komposisi spesies dari populasi gastropoda yang sama ini mencirikan bahwa pola sebaran spesies yang berkontribusi baik di bulan purnama dan perbani cenderung mengelompok. Menurut Odum (1993), adanya penyebaran kelompok individu spesies gastropoda pada suatu tempat, merupakan strategi dalam menangapi perubahan musim, cuaca, serta perubahan habitat dan proses reproduksi. Berdasarkan kedua bulan, spesies Cerithium salebrosum adalah spesies yang berkonribusi paling tinggi dan ditemukan berada pada kedua bulan tersebut, begitu pun dengan spesies Cerithium punctatum, Euthria sp. dan Troncus $s p$ tetapi memiliki kisaran nilai kontribusi berada di bawahnya. Kemunculan spesies di bulan purnama memiliki jumlah individu spesies yang lebih banyak ketimbang bulan perbani. Selain itu tingginya kontribusi spesies Cerithium salebrosum diduga memiliki tingkat penyesuaian terhadap perubahan lingkungan yang cukup baik, namun belum ada literatur yang secara spesifik menjelaskan, tetapi berdasarkan kelasnya termasuk kategori gastropoda.
Kelas gastropoda diketahui memiliki kemampuan adaptasi yang tinggi, serta beberapa jenis memiliki kemampuan bergerak (mobile) di berbagai tipe substrat untuk mendapatkan makanan. Menurut Barnes, (1987), menyatakan bahwa kelas gastropoda merupakan kelompok yang paling sukses karena mampu bertahan hidup di berbagai variasi tipe habitat. Spesies Cerithium salebrosum memiliki pola adaptasi tersendiri, dimana ketika air mengalami pasang maka spesies ini beruaya dan melakukan asosiasi mencari makan, tetapi ketika air mengalami surut maka spesies ini cenderung memendam diri di dalam substrat (infauna).

Spesies dari kelompok siput genus cerithidae memiliki cara makan tergolong herbivora dan reproduksi secara aseksual (fragmentasi), memakan alga atau pemakan suspensi (filter feeder) (Sun Qimeng, 2013). Dominasi substrat berpasir di semua stasiun dengan didapatkan kepadatan yang tinggi Cerithium salebrosum mengindikasikan bahwa spesies ini hidup dominan pada substrat berpasir. Faktor parameter lingkungan terkait substrat dan habitat vegetasi lamun diduga mempengaruhi keberadaan spesies tersebut. Hal ini dikarenakan adanya hubungan atau korelasi penyebaran spesies makrozoobentos yang bergantung pada habitat lamun sebagai tempat berlindung, memijah dan substrat dasar perairan. Nybaken dan Bertnes (2004) mengatakan bahwa ukuran partikel substrat berkaitan dengan penyebaran organisme dan kelimpahan spesies makrozoobentos dikarenakan kesesuaiannya untuk digali dari retensi air. Substrat sebagai tempat memijah dan hidup dari moluska khususnya gastropoda sangat mempengaruhi komposisi jumlah spesiesnya (Cappenberg, 2006). Akan tetapi hal ini berbanding terbalik dengan (George, 2005), yang menemukan spesies Cerithium coralium lebih banyak ditemukan di substrat berlumpur dan habitat lamun di perairan intertidal. Walaupun spesies yang ditemukan berbeda, namun memiliki genus yang sama yaitu cerithidae. Habitat lamun sebagai 
tempat beruaya, mencari makan dan berlindung juga mempengaruhi komposisi dan distribusi spesies dari kelas gastropoda. Adanya pengaruh yang signifikan dari struktur kanopi yang dibentuk oleh tegakan lamun terhadap tingginya kelimpahan populasi biota yang berasosiasi di daerah lamun pulau Bone Batang (Vonk et al., 2010). Habitat lamun yang terdiri dari jenis Enhalus acorides, Cymodocea rotundata dan Thalassia hempricii menjadi suatu ciri tersendiri kesukaan dari spesies tersebut.

Selain itu makrozoobentos diketahui sebagai penghubung dalam siklus aliran energy, dalam ekosistem perairan, makrozoobentos berperan sebagai salah satu mata rantai penghubung dalam aliran energi dan siklus dari alga planktonik sampai konsumen tingkat tinggi (Kawaroe et al, 2016). Fase bulan yang berbeda juga dapat mempengaruhi distribusi dan komposisi suatu populasi dari gastropoda yang mana sebagian memiliki karakteristik kemunculan berdasarkan fase waktu tertentu. Komposisi spesies yang berkontribusi pada bulan purnama secara keseluruhan merupakan spesies yang keberadaan kemunculan di temukan pada bulan purnama dan perbani. Sedangkan pada spesies berkontribusi di bulan perbani memiliki satu spesies yaitu Rissiona multicostata yang kemunculannya hanya terdapat pada bulan perbani, namun memiliki nilai kontribusi yang cukup besar. Sementara jenis lainya ditemukan pada bulan keduanya baik purnama dan perbani. Tingginya Rissiona multicostata memiliki nilai kontribusi yang cukup besar di bulan perbani dikarenakan spesies ini memiliki nilai kepadatan yang cukup tinggi (105 $\mathrm{ind} / \mathrm{m}^{2}$ ) pada stasiun yang ditemukan di bulan perbani.

\subsection{Korelasi Makrozoobentos dengan Penutupan Lamun}

Hasil korelasi antara persentase penutupan lamun dengan kepadatan makrozoobentos saat periode bulan purnama (a) dan bulan perbani (b) disajikan pada
(Gambar 3).
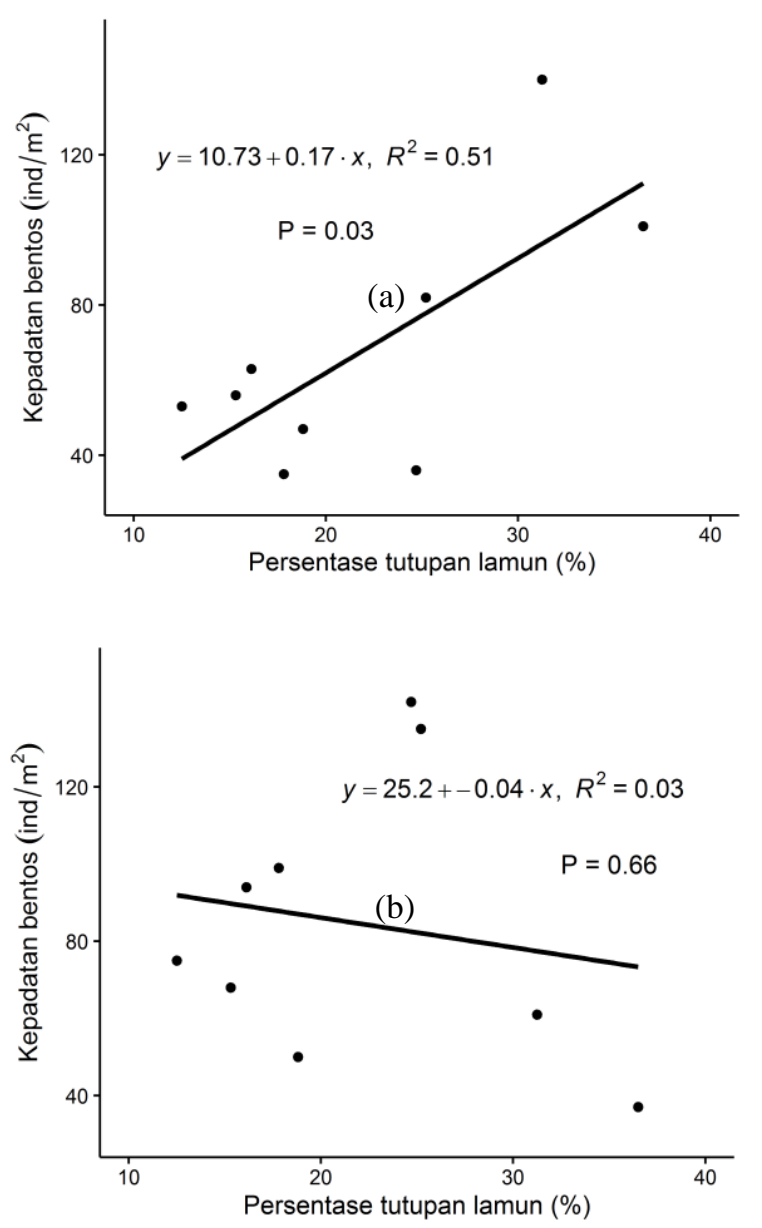

Gambar 3. Korelasi kepadatan makrozoobentos dan penutupan lamun di bulan purnama (a), dan perbani (b).

Tingginya nilai penutupan lamun mewakili tempat berlindung bagi organisme makrozoobentos tertentu baik menetap, memijah, dan meliang di dedaunan sebagai habitat. Menurut Vonk et al. (2010), adanya pengaruh yang signifikan dari struktur kanopi yang dibentuk oleh tegakan lamun (Enhalus acoroides) terhadap tingginya kepadatan populasi biota asosiasi di daerah lamun pulau Bone Batang. Penutupan lamun yang tinggi memungkinkan epifauna untuk mendapatkan tempat berlindung dan menyediakan berbagai sumber makanan. Jumlah individu terkecil baik yang ditemukan substrat dasar dan daun lamun ditemukan di lamun yang memiliki kerapatan dan penutupan yang jarang. 
Penutupan lamun yang jarang kurang memberikan perlindungan bagi epifauna karena tidak memiliki daun yang rimbun untuk menenangkan perairan dari arus dan gelombang. Hasil penelitian Cappenberg (1996), menemukan adanya korelasi positif antara penutupan vegetasi lamun dengan kepadatan makrozoobentos di pulau Osi teluk Kotania, Seram barat. Efek positif penutupan lamun secara umum terkait kompleksitas struktur kanopi dalam mendukung perekrutan, kolonisasi biota laut dan meningkatkan stabilitas sedimen.

Hasil korelasi di bulan Perbani menunjukan nilai koefisien korelasi antara kepadatan makrozoobentos dengan penutupan lamun memiliki keterkaitan tetapi hubugannya berlawanan arah ditandai dengan garis lurus yang bernilai negative (Gambar 3 (b). Semakin tinggi nilai penutupan lamun maka semakin berkurang kepadatan makrozoobentos. Nilai koefisien regresi $\left(\mathrm{R}^{2}\right)$ diperoleh 0,03 dan nilai probabilitas sebesar 0,66. Korelasi nilai penutupan lamun dengan kepadatan makrozoobentos di bulan perbani, mengambarkan bahwa penutupan lamun tidak berpengaruh signifikan terhadap kepadatan makrozoobentos. Adanya faktor lain yang mempengaruhi, baik karakteristik spesies, parameter lingkungan dan substrat. Menurut Hemminga dan Duarte (2000), keberadaan suatu jenis makrozoobentos di daerah lamun tidak bergantung sepenuhnya pada keberadaan vegetasi lamun, faktor lingkungan seperti hidrodinamika, karakter substrat, dan kedalaman juga mempengaruhi. Tingginya penutupan lamun memiliki hubungan yang lemah dengan kepadatan makrozoobentos di habitat lamun pulau Panggang. Penutupan lamun yang tinggi dapat menghambat proses pergerakan organisme makrozoobentos tertentu dalam bergerak terutama organisme makrozoobentos yang bersifat mobile. Menurut Ringold (1979), adanya efek dari lapisan rimpang dan padat daun lamun Zostera Nolti secara spesifik menghambat pergerakan organisme epifauna dan infauna yang memendam ke dalam substrat.

Selain itu faktor fase bulan pada saat sampling data makrozoobentos mengindikasikan bahwa adanya karakteristik spesies yang durasi kemunculan berdasarkan periode bulan tertentu. Kecendrungan kemunculan spesies tersebut berpengaruh terhadap kepadatan spesies makrozoobentos pada masing-masing periode waktu di ekosistem lamun. Keterkaitan antara kepadatan spesies dan fase bulan terutama bulan purnama dikarenakan terkait dengan pencahayaan bulan saat purnama yang dapat mengstimulasi biota laut untuk dapat berasosiasi. Adanya asosiasi saat purnama ini yang diduga menjadi indikator terdapat perbedaan kepadatan makrozoobentos pada bulan purnama dan perbani yang ada di perairan pulau Panggang Kepulauan Seribu.

\subsection{Keberadaan Populasi}

\section{Makrozoobentos di Pulau Panggang}

Terdapat 5 populasi makrozoobentos yang ditemukan pada saat sampling di bulan purnama dan perbani di perairan pulau Panggang yaitu gastropoda, crustacea, ekhinodermata, bivalvia dan porifera (Gambar 4).

Berdasarkan pengelompokan spesies yang muncul pada periode waktu tertentu, didapatkan bahwa spesies makrozoobentos yang muncul pada saat periode bulan purnama terdiri dari kelas bivalvia $24 \%$, crustacean $2 \%$, gastropoda $72 \%$ dan kelas porifera $2 \%$. Periode bulan perbani spesies makrozoobentos yang didapatkan terdiri dari echinodermata $5 \%$, bivalvia $13 \%$, porifera $3 \%$, crustacean $3 \%$ dan gastropoda $76 \%$ (lampiran 5). Sedangkan pada periode waktu bulan kedua duanya didapatkan bahwa adanya 3 kelas yang terdiri dari bivalvia $16 \%$, porifera $4 \%$, dan gastropoda $80 \%$. Kemunculan beberapa spesies di atas ditandai dengan dominasi dari salah satu genus yaitu gastropoda dengan angka persentasi berkisar $72-80 \%$ pada masingmasing periode bulan. Hal ini berbanding terbalik dengan Sanders (1968), menyatakan 


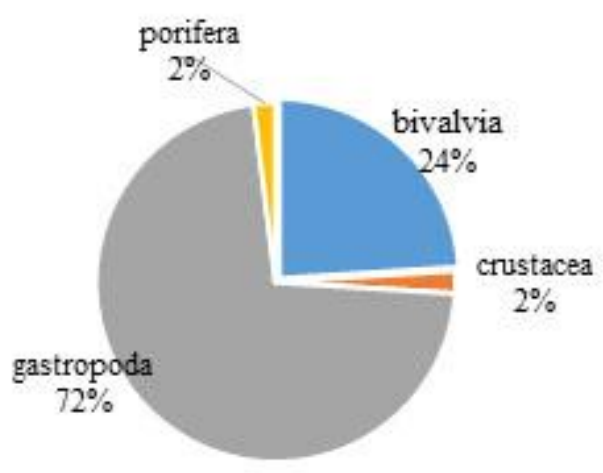

A

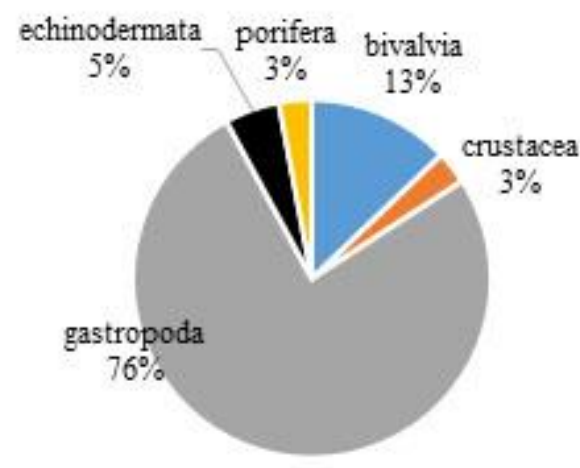

B

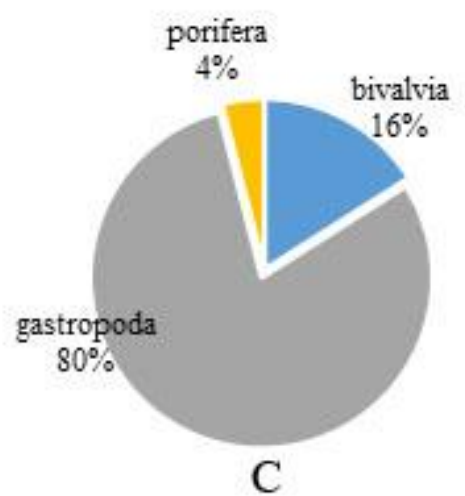

Gambar 4. Persentasi ditemukan populasi spesies makrozoobentos pada bulan purnama (A), perbani (B) dan keduanya (C).

umumnya komposisi hewan moluska di segala area terdiri dari kelompok polichaeta 50-60\%, sedangkan sisanya adalah crustacea, gastropoda dan echinodermata.

Perbedaan parameter yang berkorelasi antara kedua periode waktu ini, memicu munculnya organisme pada suatu habitat dengan komposisi kelimpahan berbeda. Hal ini terlihat dengan dominasi komposisi spesies makrozoobentos dari gastropoda dan bivalvia. Menurut Hendrick et al. (2007), menyatakan bahwa gastropoda dan bivalvia merupakan penyusun komunitas makrozoobentos di kawasan perairan pantai. Banyak kedua genus ini menandakan bahwa spesies tersebut mempunyai tingkat adaptasi yang baik terhadap substrat berpasir dan vegetasi lamun. Sehingga keberadaan substrat dasar perairan, vegetasi lamun dan fase waktu di saat penelitian mendukung kelimpahan dan keragaman makrozoobentos khususnya gastropoda. Gastropoda juga tergolong herbivore dan pemakan detritus (detritus feeder) dengan menyerap partikel organik pada dasar perairan. Namun faktor eksternal juga mempengaruhi keberadaan spesies gastropoda dan organisme lain diperairan pulau panggang. Adanya pengaruh antropogenik dari daratan yang menyebabkan banyak spesies gatsropoda yang mati dan menyisahkan cangkangnya. Menurut hasi penelitian Madduppa et al. (2013), ekosistem yang ada di kepulauan seribu baik terumbu karang dan organisme lainya mengalami pengaruh dari dampak aktivitas antropogenik. Hal ini didukung dengan banyaknya ditemukan cangkang-cangkang mati pada saat sampling dilapangan, namun tidak di data secara kuantitatif. 


\section{KESIMPULAN}

Kepadatan spesies makrozoobentos menunjukkan perbedaan nyata antara bulan purnama dan perbani, namun tidak pada kepadatan individu. Spesies makrozoobentos yang paling berkontribusi pada bulan purnama dan perbani, yaitu Cerithium salebrosum. Terdapat korelasi positif antara kepadatan makrozoobentos dengan penutupan lamun di bulan purnama, sedangkan perbani berkorelasi negatif.

\section{UCAPAN TERIMA KASIH}

Ucapan terima kasih disampaikan kepada LPDP lembaga pengelola dana pendidikan yang telah membantu biaya penelitian ini, tak lupa juga kepada teknisi dan teman-teman di Laboratorium Biologi Mikro (BIMI) Departemen Manajemen Sumberdaya Perairan FPIK IPB.

\section{DAFTAR PUSTAKA}

American Public Health Association (APHA). 1992. Standard methods for the examination of water and waste water, $16^{\text {th }}$ ed. American Public Health Association. Washington DC. $76 \mathrm{p}$.

Barnes, R.D. 1987. Invertebrate zoology. Saunders Collage Publishing. Philadelphia. 893p.

Bengen, D.G. 2002. Teknik pengambilan contoh dan analisis data biofisik statistik sumber daya pesisir. PKSPBL-IPB. Bogor. 89hlm.

Cochran, W.G. 1977. Sampling techniques $3^{\text {rd }}$ Edition. Harvard University, United State of America. New York. 428hlm.

Clarke, K.R. 1993. Non parametric multivariate analyses of change in community structure. Australia Journal Ecology 18.117-143.

Cappenberg, H., A, W., A, Aziz., dan I, Aswandy. 1996. Komunitas moluska di perairan teluk Gilimanuk. Bali Barat.Oseanologi dan Limnologi di Indonesia. 39:75-87

Cappenberg, H.A.W. 2006. Komunitas moluska di perairan teluk Gilimanuk. Bali Barat. Oseanologi dan Limnologi di Indonesia. 40:53-64.

De Wilde, P.A.W.J. 1989. Structure and energy demand of benthic soft-bottom communities in the java sea and around the islands if Madura and Bali Indonesia. Nether J. Sea Res, 23. 449461.

Day, J., W. Hall, Cas, W.M. Kemp, dan Yanez, and A. Arancibia. 1989. The esturine bottom and benthic subsystem. In: JW Day (eds) Estuarine Ecology. Wiley \& Sons, New York, 338-376pp.

Dharma, B. 1992. Siput dan kerang Indonesia (Indonesian shells II). Wiesbaden, Hemmen. 135hlm.

Dharma, B. 2005. Recent \& fosil Indonesia Shell. Conchbooks, Mainzer str, Hackenheim. 424hlm.

English, S.W.C. and V. Baker. 1997. Survey manual for tropical marine resources. Australian Institute of Marine Science. Townsville. Germany. 390hlm.

Hendrick, M., E. Brusca, R.C.M. Cordero, dan G. Remirez. 2007. Marine and brackish-water molluscan biodiversity in the of California, Mexico. Scientia Marina, 71(4):637-647.

Hemminga, M., A. dan C.M. Duarte. 2000. Seagrass ecology. Cambridge University Press. Inggris. 298p.

Kawaroe, M., Nugraha, AH., Juraij., I. Tasabaramo. 2016. Seagrass biodiversity at three marine ecoregions of Indonesia, Sunda Shelf, Sulawesi sea and Banda Sea. Indonesia. Bio Diversitas, 7(2):585-591. doi: 10.13057/biodiv/d170228.

Legendre, P.S., F. Thrush, V.J. Cummings, P.K. Dayton, J. Grant, J.E. Hewitt, A.H.Hines, B.H. McArdle, R.D 
Pridmore, D.C. Schneider, S.J. Turner, R.B. Whitlach, dan M.R Wilkinson. 1997. Spatial structure of bivalves in a sandflat; scale and generating processes. $J$. of Experimental. Marine Biology, 216: 99-128.

Latuconsina, H. 2012. Sebaran spatial vegetasi lamun (seagrass) berdasarkan perbedaan karakteristik fisik sedimen di perairan Teluk Ambon. $J$. Ilmu dan Teknologi Kelautan Tropis, 4(1):198-203.

McLusky, DS. 1989. The estuarine ecosystem ( $2^{\text {nd }}$ edn) Chapman and Hall, London. P. 133.

Madduppa, H., B.Subhan, E. Suparyani, A. Siregar, M. Arafat, D. Tarigan, Alimuddin, D. Khairudi, F. Rahmawati, and A. Bramandito. 2013. Dynamics of fish diversity across an enviromental gradient in the Seribu Islands Reefs off Jakarta. Biodiversitas, 1:17-24 doi: 10.13057/ biodiv/d140103.

Nybaken, J. dan M.D. Bertness. 2004. Marine biology: an ecological approach. $\quad 6^{\text {th }}$ ed. Benjamin Cummings. $15 \mathrm{p}$.

Odum, E.P. 1993. Dasar-dasar ekologi. Gadjah Mada University Press. Yogyakarta. $546 \mathrm{hlm}$.

Pearson, Prentice, Hall. 2007. Applied multivariate statistical analysis. Edisi keenam. Upper Sadlle River: Pearson Prentice Hall. New Jersey. 773hlm.

Ringold, R. 1979. Burrowing root mat density and the distribution of fiddler crabs in the eastern United States. $J$. Exp Mar Biol Ecol., 36, 11-21.

Romimoharto, K. dan S. Juwana. 2004. meroplankton laut: larva laut yang menjadi plankton. Djambatan, Jakarta. 214hlm.

Sanders, H.L. 1968. Marine benthic diversity: a comparative study. Am. Nat., 102:243-282.

Schneider, D.C. 1994. Quantitative ecology; spatial and temporal scaling. Academic Press. San Diego. 395p.

Sun, Q. dan S. Zhang. 2014. A new species of Cerithium (Gastropoda: Cerithidae) from the south China sea. $J$. of oceanology and limnology. 32(5):1118-1122.

Tomasick, T., A.J. Mah, A. Nontji, M.K. Moosa. 1997. The ecology of the indonesia seas. Part One Periplus Edition. Singapore. 900p.

Departement of Agriculture; natural resources conservation service (USDA NRCS). 2012.. $3^{\text {rd }}$ ed. Field book for describing and sampling soils Washington DC (US), USDA. 300hlm.

Vonk, J.A., M.J.A. Christianen, dan J. Stapel. 2010. Abundance, edgge effect and seasonality of fauna in mixed-species seagrass meadows in South-west Sulawesi, Indonesia. Mar. Biol. Res., 6:282-291.

Waycott, M., K.M. Mahon, J. Mellors, A. Calladine, and D. Kleine. 2004. A guide to tropical seagrass of the Indowest pacific. Townsville-Queensland, James Cook University. Australia. 236p.
Diterima
: 22 Desember 2017
Direview
: 07 Januari 2018
Disetujui
: 23 April 2018 
